\title{
Disability's Circularity: Presence, Absence and Erasure in Australian Settler Colonial Biopolitical Population Regimes
}

\author{
KAREN SOLDATIC \\ Western Sydney University, Australia
}

\begin{abstract}
In this paper, I explore the ways in which settler-colonial states utilize the category of disability in immigration and Indigenous population regimes to redress settler-colonial anxieties of white fragility. As well documented within the literature, settler-colonial governance operates a particular logic of population management that aims to replace longstanding Indigenous peoples with settler populations of a particular kind. Focusing on the case of Australia and drawing on a range of historical and current empirical sources, the paper examines the central importance of the category of disability to this settler-colonial political intent. The paper identifies the breadth of techniques of governance to embed, normalize and naturalize white settler-colonial rule. The paper concludes with the suggestion that the state mobilization of the category of disability provides us with a unique way to identify, understand and analyse settler-colonial power and the interrelationship of disability, settler-colonial immigration regimes and Indigenous people under its enterprise.
\end{abstract}

KEYWORDS disability; impairment; settler colonialism; Australia; Indigenous; migration

\section{Introduction: Disability Circularity and Settler-colonial Power}

It is well established within international literature that settler-colonial societies have a complex set of governance practices that have been, and remain, determined by the logic of colonial power (Morgensen, 2011). Veracini (2014) has argued that the logic of colonial power within the settlercolonial landscape is quite distinct to that of colonization. Veracini suggests that this distinction needs to be understood as that shaped by distance and dispossession. Colonization was shaped by its distance - a governing of faraway lands, waters, species and peoples, whose resources and labour power 
were exploited, extracted and brought back to the centre of colonial power for colonial appropriation.

Settler colonialism is marked by its focus on "accelerated reproductive capacity" (Veracini, 2014, p. 616) as a distinct form of colonial power. Settler colonialism seeks to dispossess its colonized territories of lands, waters, species and peoples for settlement by the colonizer. The rapid reproduction of settler humans, their animals, plant life and other species on these stolen lands is the point at which colonial power is established. That is, the colonial power is aimed at embedding, normalizing and naturalizing the settler on stolen lands and territories. The aim is to remove the presence of those who came before, "the prior," "the indigene," "the first," so that the presence of the settler-colonial state is understood as all that has existed in place, as though there were nothing before the settler's arrival. Thus, while colonization extracted and appropriated from a distant centre of power, settler-colonial governance dispossesses through direct strategies of elimination, to make totally absent those who came before (Veracini, 2014). Patrick Wolfe (2006) anticipates Veracini's arguments, stating that "settlercolonialism destroys to replace" (p. 387).

Feminist scholars examining historical developments within settler colonialism have also suggested that this focus on settler population naturalization and, in turn, its concentration of accelerated reproduction, has meant that within the settler colony, women's reproductive capacities and sexuality have come under particular scrutiny (Bashford, 2004). Carol Bashford (2004) has mapped out the ways in which heteronormative reproductive controls were critical to settler-colonial governance in Australia. This is done in two ways, firstly by monitoring white women's fecundity and establishing state practices to encourage white women's reproduction (Soldatic, 2015). Secondly, Indigenous queer scholar Madi Day (2019) has argued that the settler-colonial preoccupation with population replacement is a unique form of heteronormative governance over Indigenous peoples, involving monitoring interracial marriages between white men and Indigenous women, and Indigenous community sexual practices and identities. All of this work empirically confirms Veracini's (2014) suggestion that settler colonialism is marked by political narratives of reproductive urgency, such as in Australia where the "populate or perish" theme dominated in the inter-war years. Combined, these scholars suggest that settler-colonial relations of power lead to a very specific form of biopolitical management, which promotes the desire to naturalize settler-colonial power.

Interestingly, despite broad scale recognition of the importance of biological reproduction for furthering settler-colonial power on stolen territories, few settler-colonial scholars have considered the central importance of the category of disability within this paradigm. This is curious given that eminent disability scholars have mapped out the important role of disability in the rise of eugenics as the vanguard of turn-of-the-20th-century nationalism (Mitchell \& Snyder, 2015). Disability scholars, too, have 
neglected to differentiate between settler colonialism and colonialism, in terms of the nuances of these two different relationships of power. In both fields of scholarship, while disability is present, settler colonialism is absent, and vice versa.

In this paper, my aim is to outline the importance of the disability category for settler colonial securitization on stolen Indigenous lands. Employing a range of empirical material, I show how the category of disability in settlercolonial Australia was and is used to control and sustain territorial borders, and to dispossess Indigenous peoples of their lands and communities. The analysis is both historical, at the point of nation-state formation in 1901, and contemporary, with the advent of neoliberal settler-colonial rule.

I examine three strategic sites of intervention: first, Indigenous population management; second, migration and offshore detention; and third, the gendered relations of Indigenous disability care and migrant labour regimes. This analytical juncture responds to the work of Chatterjee (2019), who has consistently argued for greater depth to our analyses of systems of racialized power within the contemporary settler-colonial state. It also seeks to address the tensions raised in Rachel Gorman's (2016) critical work on dominant narratives within disability, which argues for the need to be explicit about biopolitical practices that are ableist and highly racialized. Through its circular mobilization across, through and within different settler-colonial biopolitical instruments of power, disability factors importantly in the biopolitical techniques of governance that break down Indigenous bodiesand-minds and immigrant bodies-and-minds, and generate impairment. By further scrutinizing settler-colonial capitalist logic and practice, and disability scholarship on nation-state formation, I argue that it is also possible to identify the governance techniques that extract value from bodies-and-minds and, in turn, reproduce disability in much higher proportions within the ongoing regime of settler colonialism.

My aim is not to conflate biopolitical techniques of settler-colonial governance with either disability or race, but to make visible the role of the category of disability in settler-colonial governance to erase impairment from all spheres of Australia's claims to territory. I use the notion of circularity to illustrate how disability is mobilized to secure the settler-colonial state. This circular movement through the axis of presence, absence and erasure, mobilises bodies-and-minds through circuits of settler colonial power - at times used to mark out disability's presence to dispossess Indigenous peoples, at other times through strategically making disability absent to hide the ongoing violence of settler colonial rule, and finally, the erasure of disability to hide white settler colonial anxieties. As argued throughout this paper, disability persists and is reproduced by and through settler-colonial regimes and their ontoformative outcomes on bodies-and-minds. 


\section{Disability, Dispossession and Death: Indigenous Population Management}

Socio-legal constructions of nationhood with the formation of settler colonialism rendered Indigenous bodies-and-minds invisible in the Australian constitution. Indigenous peoples were explicitly erased not only through their absence from the constitution (Povinelli, 2011), but also through the nation's racialized governance with the false claim of terra nullius - that the Australian settler colony was formed on lands never inhabited by a prior peoples (Rose, 2004). Such socio-legal constructions make visible the white settler's desire to erase Australia's Indigenous peoples, a form of social, cultural and political death (Rose, 1999). Australia was exemplary in its framing of white settler-colonial biopolitical structures, as it "assumed the elimination by expulsion onto 'reservations' or by genocide" (Hobsbawm, 1987, p. 24) of its Indigenous peoples. It imagined a past without its Indigenous peoples at the moment of its constitutional formation, whilst imagining its future as a particular bodily formation. Even though Indigenous peoples have mobilized for an alternative constitutional framework with the Uluru Statement (a joint statement on Indigenous sovereignty, rights and territory), this claim for recognized presence has been rejected by white settler-colonial political elites, including prime ministers and other national leaders (see Wahlquist, 2017). The struggle for recognition, fair and just representation, and territory and sovereignty continues to remind the settlercolonial population of its anxious insecurities and vulnerabilities, and of the enduring presence of Australia's First Peoples (Ravenscroft, 2012). That is, Indigenous peoples will not be erased.

To counter Indigenous claims for justice, settler colonialism makes the presence of Indigenous peoples known by bringing to the fore discourses of disease, deficiency, death and decay, drawing on highly medicalized discourses of disability through the realm of statistical counting. Indigenous scholar Maggie Walter (2016) argues that Indigenous' ongoing presence under the veil of settler-colonialism is only ever made known through statistical regimes that pivot around the five Ds of settler-colonial data: Indigenous disparity, deprivation, disadvantage, dysfunction and difference. Thus, data collection is mobilized to measure the exceptionality of Indigenous peoples within the Australian settler-colonial state as a means to separate the settler from the Indigene. The marking out of Indigenous people as a site of exceptionality circles back to disability as a site of settler-colonial power. Absent from these statistical narratives is the ways in which disability appears in Indigenous peoples as the embodiment of settler-colonial relations of power (Connell, 2011). Drawing on the concept of ontoformativity, Connell's (2011) work illustrates that disability exists in an ontoformative relationship with power relations. Soldatic (2018), drawing on Connell's work, documents this in settler-colonial Australia to show how ontoformativity generates high rates of disability for Indigenous peoples through settler colonial violent rule, and also how disabled Indigenous 
peoples are mobilized through unique structures of settler-colonial racialised regimes of ableism.

The clearest example of how ontoformativity is realised in current settlercolonial regimes is the more recent developments in neoliberal welfare-towork policies and how the disability category is used to reestablish longstanding divisions between the deserving and undeserving of redistributive welfare (Soldatic \& Fitts, 2020). Even as disability is clearly made visible through statistical counts that document Indigenous rates of disability as at least twice that of settler populations (Australian Bureau of Statistics, 2017a, 2017b), the disability category within Australia's welfare regime has become increasingly tightened. Since 2015 , over 200,000 people living with severe disabilities, chronic conditions and illness are no longer deemed disabled and are moved onto general unemployment benefits (Soldatic \& Fitts, 2018). General unemployment social security payments are not only lower cash transfers with significantly lower entitlements, but impose new forms of conditionality to ensure that unemployed disabled people remain "engaged" and "active," with their bodies-and-minds mobilized in circular movements across a range of welfare landscapes (Soldatic \& Fitts, 2020). To maintain access to their welfare payments Indigenous Australians living with disability have to move from medical appointments to Government welfare offices and then specialist employment providers in a continuous circular movement to ensure ongoing access to welfare (Soldatic, 2018). Indigenous peoples living with disability are particularly vulnerable to the contradictory effects of this neoliberal welfare regime, which both count the heightened statistical representation of disability within Indigenous people whilst simultaneously denying them access to disability social protections for not being "disabled enough" (Soldatic, 2018).

Indigenous peoples living with disability are propelled onto highly conditional income-management regimes managed by technical experts of disability welfare governance and surveillance (Bielefeld, 2016). Through these neoliberal surveillance regimes, Indigenous peoples living with impairment are required to make themselves known to able-bodied social security workers who monitor their ongoing compliance to settler-colonial systems of power, which simultaneously propels settler-colonial narratives of Indigenous exceptionality. Failing to "comply" because of the ontoformative outcomes on their bodies-and-minds of settler-colonial rule - that is disability - propels them deeper into the assemblage of neoliberal welfare surveillance to ensure that their only form of mobility is determined by the power of the settler-colonial state. Disability's circularity simultaneously erases settlercolonial dispossession, erases its ongoing power over Indigenous peoples, yet makes present settler-colonial statistical framings of Indigenous bodies-andminds (Soldatic, 2019). Its circularity is thus always central to settler-colonial anxieties of securitization. Settler colonial racialized violence, conversely, 
mobilises disability differentially within its border regimes through making the presence of disability known.

\section{Disability \& Immigrant Exceptionality}

It is said that we live in a time of chronic mobility. The movement of people across borders is unprecedented in modern times, with the United Nations High Commissioner for Refugees (2019) declaring that human movement across national borders and boundaries has surpassed that occurring in World War II. The mass movement of bodies-and-minds has become highly visible. Our online screens, social media sites such as Facebook and Twitter along with our Instagram networks, remind us of the sheer velocity of bodies-andminds on the move with the destruction of nations, communities and peoples. Syria has alerted the world once again to the vast devastation caused by war and armed conflict. This mobility is unprecedented not only in numbers but also in the highly militarized violence that plagues our embodied vulnerabilities, temporalities and situated logic of settler colonial securitization.

\section{Disability and Racialized Management at the Border Through Entry Policies}

Settler-colonial Australia has been at the forefront of highly racialized immigrant population management. Its national classificatory logic of inclusive citizenship is grounded not only in European invasion but also in its formation as a nation with its constitutional framing in 1901. Internal population regimes to address settler-colonial anxieties of securitization are coupled with the biopolitical management of immigrant flows at the border. And the presence of disability, disease and potential death circulates through immigrant governance regimes in interrelated processes. Disability has a relationality between the immigrant body-and-mind and Indigenous peoples within the settler colony of Australia. Disability has been mobilized by the settler colonial state at key historical moments, extending beyond the original colonial strategy of externalizing disability through closing down territorial borders to its very possibility, which began with Australia's first national parliamentary act, the Immigration Restriction Act 1901. White colonial settlers imagined the body politic of the nation as white and able-bodied. Whilst the constitution denies the presence of Australia's Indigenous peoples, the Immigration Restriction Act explicitly excluded the disabled immigrant at the nation's border. This Act, the foundation of the White Australia policy, is internationally known for its racialization of border control. Lesser known is its marking out of disability with the explicit exclusion of "any idiot or insane person" or "any person suffering from an infectious or contagious disease of a loathsome or dangerous character" (Immigration Restriction Act 1901 s3 (c) 


\section{Karen Soldatic}

\& (d)). The disabled immigrant was central to white settler-colonial discursive positionings that situated whiteness as biological purity, free from disease and disability. Thus, the visibility of disability operated as the underlying logic of a moral-political imaginary for a new nation that explicitly cleansed itself of its past (Soldatic \& Fiske, 2009). The formation of a white Australia, as a national "body" politic, was the "confluence of border controls and public health measures, underpinned by medical science" (Jakubowicz \& Meekosha, 2003, p. 180). Disability is well established in transatlantic scholarship surveying the critical role of eugenics in maintaining colonialised governance (Bashford, 2004; Jarman et al., 2002), and in Australia the hunt for disability was central to settler-colonial political history (Baker, 2002). ${ }^{1}$

Whilst the White Australia policy was officially withdrawn in the early 1970s (Fleay, 2015), settler-colonial anxieties surrounding the possibility of disability breaching the border have retained their salience (National Ethnic Disability Alliance, 2015). Even the Migration Act 1958 - the legislation designed to replace the Immigration Restriction Act - is marked by the continuity of settler-colonial anxieties. Disability is made explicit in the Migration Act via the requirement of stringent medical assessment for all potential migrants. The hunt for disability in Australia's settler-colonial immigration regime is a highly formulated process relying on statistical calculations of significance. This affirms Levy and Peart's (2004) suggestion that the settler colonial state's use of statistical prejudice in immigration regimes is one of continuity from the eugenics period to the present. If disability is shown to be present, or potentially present in the bodies-andminds of potential immigrants at some time in the future, an economic calculation is made to attempt to measure its so-called future cost burden on the settler-colonial state (St Guilluame \& Finlay, 2018). In utilising highly specific medical assessment technologies, the settler-colonial state aims to neutralise the historical continuities of its eugenic logic by inscribing disability with a productive value of exchange. At the moment of body-andmind assessment, this value is made against the imaginary of the fit, productive, white, able-bodied citizen as a point of comparison in some future time. Past, present and future anxieties of the settler-colonial state are hidden through these biopolitical practices of the border. Thus, settlercolonial anxieties for securitization on stolen lands circle back to disability.

This became most evident with the passage of the Disability Discrimination Act 1992. While reforms to the Migration Act 1958 replaced the visible racialization of Australia's settler-colonial border regime, the Act remains the only piece of legislation exempt from the Disability Discrimination Act. Disability's place of exceptionality is not without

\footnotetext{
${ }^{1}$ In line with Baker's (2002) historical account of disability within settler colonial education policy, I utilise the notion of "hunt/hunting for disability" to signify disability's refusal to be erased even as the settler colonial state seeks it out for erasure and elimination.
} 
temporal significance. The Disability Discrimination Act was established in the same year as Australia introduced its mandatory detention policy for all unregulated migrants (Soldatic \& Fiske, 2009). Disability's presence works in tandem with, and circles back to, the settler colonial anxiety to secure the borders that never belonged to them.

\section{Disability and Offshore Detention Centres}

Despite the global displacement of vast numbers of people, numerous nationstates are closing their borders to refugees. Now more than ever, there is a global presence of harsh policies of mandatory incarceration, both on and off shore, and at the fringes of borders. The incarceration of immigrant bodiesand-minds, young and old, offers a level of visibility, although the strategic intent is to make invisible the new immigrant arrivals. Many of the very nation-states that ratified the 1951 UN Convention on Refugees (including Australia) have established the harshest regimes of indefinite incarceration (Rice et al., 2018). The massive increase in indefinite detention centres has normalized immigration spaces of incarceration, removing them from exceptionality. It is now often argued that immigration detention centres are the norm of global migration geopolitics of territoriality (see Flynn, 2016). While the bodies-and-minds, peoples and communities incarcerated inside these walls disappear from our memories, the symbolism of rejection, despair and exclusion in the fences, barbed wired and interlocking walls of the detention centre is highlighted by the nation-state so as to crush the desires of desperate others, in a geopolitics of deterrence (Watkins, 2017).

The detrimental impacts of mandatory incarceration illustrate Connell's (2011) proposition surrounding the ontoformative effects on bodies embroiled in relations of power. As well documented in the media (Barrett \& Barlow, 2014; BBC News, 2016) and in scholarly research, ongoing offshore incarceration generates severe human distress, disablement and immeasurable suffering (Fleay, 2015; St Guillaume \& Finlay, 2018). The temporality of indefinite incarceration creates newly formed ontoformative vulnerabilities of mental illness and suicidality, and reproduces many of the very vulnerabilities that one's mobility had hoped to avoid, involving the destruction of one's body, mind and spirit (Amnesty International, 2012, 2014). Hope is displaced by despair, desperation with enduring forms of intolerable suffering. The slow breaking down of bodies-and-minds, the very intimate bonds of sociality that one sought to protect, the slow death of the soul, make the visible presence of distress, disability and death a pernicious practice of state-generated social suffering (National Ethnic Disability Alliance, 2015).

The erasure of asylum seekers and refugees from the settler-colonial imaginary has been actively sought through the banishment of racialized bodies-and-minds off shore excised from Australian territoriality (Poynting \& 


\section{Karen Soldatic}

Briskman, 2018). Established in poor developing nations within the AsiaPacific borderlands, these off-shore detention centres are not only the places that contain non-white bodies-and-minds seeking asylum in Australia, but also have become places that manufacture disability with the harms generated by their very walls (St Guilluame \& Finlay, 2018). The Australian settler state has privatized and outsourced the running of the centres to some of the largest global contractors, and paid previously colonized territories to host them. Through years of incarceration the presence of disability becomes visible in the bodies-and-minds of those forced within their confines for indefinite immigration detention. Rather than erasing disability by placing people out of sight, the very act of banishment has an ontoformative effect that generates disablement, cycling through disability's material embodiment.

\section{Gendering Indigenous and Immigrant Disability Circularities}

Immigrant and Indigenous population strategies of biopolitical management regimes coexist around the gendering of reproductive control and practices of care (Soldatic, 2015). These practices are gendered and gendering through the pursuit of highly invasive medical regimes and practices of child removal alongside national narratives of responsible regimes of care for others as a deliberate display of caring for, and about, the settler-colonial nation (see Soldatic \& Fitts, 2020). Reproductive controls, to forfeit disabled and Indigenous women's fertility, proliferated across the Australian settler colony with its formation as a new nation in the early 1900s (Soldatic, 2020). National strategies promoted the reproduction of the white settler-colonial polity through so-called positive eugenic strategies such as pro-birthing strategies for white, middle-class, settler-colonial women, which operated via broad scale maternal hygiene and social security regimes, involving national maternal payments and public maternal health care. These were coupled with strategies of "negative" eugenics in relation to Indigenous and racialized women through such practices as sterilization, withholding of maternal social security payments and health services (Soldatic, 2015). These biopolitical practices were critical to the white, able-bodied, settler-colonial imaginary that sought to secure the lands of which Indigenous peoples were dispossessed. These strategies of settler-colonial biopolitics were aimed at erasing the presence of Indigenous and disabled peoples to address settlercolonial anxieties of their own vulnerability and fragility. Negative reproductive controls of disabled women's and Indigenous women's bodies thus pursued erasure not only of highly racialized and disabled bodies, but also revealed the haunting continuity of white settler-colonial vulnerability.

While such gendered practices of reproductive controls have now been marked as discriminatory and illegal in most of Australia, the settler-colonial state, with the onset of neoliberal biopolitics, has developed a confluence of heteronormative techniques of power and practices of governance that 
represent what Deborah Bird Rose argues is a form of "deep colonisation," where the "colonising practices... may conceal, naturalise, or marginalise, continuing colonising practices" (Rose, 1999, p. 189). Deborah Bird Rose illustrates how settler colonial state practices that purport to be empowering and decolonizing, further embed settler colonial power over Indigenous peoples (Marchetti, 2006). Disability's circularity here operates through racialized processes of gendered relations of care that are central to gendered immigration labour regimes (Burns, 2019).

In Australia, settler-colonial practices of immigration control are increasingly propelling poor, immigrant women of colour into secondary care-labour markets on Indigenous lands and country in outer urban areas and rural Australia (Peisker \& Tilbury, 2006). Immigration regimes seek to push the labour power of poor women of colour to the edges of urban landscapes and to the depths of Indigenous lands through quantitative weightings granted to poor immigrants who will reside in rural and remote areas of the settler colony for extended periods of time (Goel \& Penman, 2015). Bodies of colour come together in distant Indigenous lands to care for each other, where migrant women are willing to provide low-paid care for Indigenous strangers, and facilitate disability relations of care in rural and remote Indigenous communities (Adamson et al., 2017; Morrison-Dayan, 2019).

These gendered and racialized regimes of disability care labour address settler-colonists' anxieties, as it enables them to continue to make absent from national narratives the devastating longstanding ontoformative effects of settler-colonial rule on Indigenous peoples. Paradoxically, Indigenous people with disability are seen as complicit in the wearing down of the bodies of poor immigrant women, who are propelled into unprotected and barely regulated precarious care-labour markets (Reid et al., 2016). While these migration regimes of care labour appear to recognize the care needs of Indigenous peoples and purport to support their Indigenous practices of care within the community, these regimes of care continue the settler colonial project through the precarious care labour of immigrant women. New immigrant care-labour regimes within the settler colonial state are thus a deeper form of colonization, as Deborah Bird Rose (1999) has continued to demonstrate. Settler colonial articulations of gendered relations of care is thus a highly racialized process (Howard-Wagner, 2016). At the same time, immigrant care regimes are misrepresentations of Indigenous women's care labour within the settler-colonial enterprise and its gendered-racialised stigmatisation. To reiterate Elizabeth Strakosch's (2016) point, "Indigenous groups are rendered as objects of settler governmental care and control" ( $\mathrm{p}$. 68 ), to naturalise the ongoing denial of sovereignty.

The techniques of governance, the boundaries of rule and repertoires of population patterning, combined strategies of scientific racism with that of scientific ableism (Soldatic, 2015). It is now well documented that the settlercolonial strategy of separating Indigenous mothers from their children was central in attempts to erase Indigenous peoples with the advance of eugenic 
ideologies of racialization (Atkinson, 1990). Despite national recognition of the ontoformative effects of longstanding child removal, such as intergenerational trauma, today Indigenous women and mothers, along with disabled mothers and carers, endure the highest rates of child removal (Australian Institute of Family Studies, 2016; Human Rights and Equal Opportunity Commission, 1997). The continuity of settler-colonial governance in Indigenous women's lives, including the continued practice of child removal, undermines their capacities to care for children, family members and extended kin (Cutcher \& Milroy, 2010).

Malone (2014) argues that normative constructions of caring for others mean that disabled mothers are under constant surveillance, where small "misdemeanors" inscribe them as deviant, incapable mothers. Disabled Indigenous mothers and carers who provide care for family members with disability seek to make invisible the ontoformative effects of longstanding settler-colonial rule within their own bodies, while making visible the impairment in the bodies of those they care for, a result of settlercolonialism's intergenerational transference (Miller et al., 2017). The settlercolonial racialized project of Indigenous erasure combined with the settlercolonial state's continual hunt for disability, is both gendered and gendering, circulating through Indigenous women's practices of care for others and for themselves.

It also misrecognizes their claims for self-care as disabled women who provide care for others within their familial and kinship networks. Through welfare-to-work regimes that have tightened the disability category for redistributive cash transfers, the settler-colonial state can hunt for disability to address its biopolitical anxieties. As Soldatic and Fitts (2020) discuss, disabled Indigenous women who care for other family members living with disability increasingly feel the surveillance of the settler-colonial state in their capacity as disabled carers. While immigrant care labour regimes propel women of colour to Indigenous lands and country, building connectivity through settler-colonial circuits of gendered labour, this pushing out enables the settler-colonial state to place its own anxieties of securitization at a distance. Simultaneously, it erases from the national narrative the ontoformative impacts on Indigenous peoples of longstanding settler-colonial rule. Disability's circularity is thus mobilized to erase the possibility of settler-colonial anxieties.

\section{Concluding Circularities}

Settler-colonial strategies of disability containment, control and elimination are by their nature contradictory as the number of people living with an impairment, illness or chronic condition has persisted over time. Further, settler-colonial biopolitical practices create impairment in the very process of trying to eliminate it - the ontoformative effects of settler-colonial power. As 
discussed throughout this paper, Indigenous bodies-and-minds are intergenerationally embroiled in the ontoformative outcomes of settlercolonial anxieties to secure stolen Indigenous lands, which are themselves productive of impairment. Through settler-colonial immigration regimes that rely on strategies of expulsion, impairment is generated in the bodies-andminds of asylum seekers, refugees and migrants incarcerated in off-shore processing detention centres. Despite the mythologies of biopolitical screening and assessment devices to erase disability from the settler-colonial imaginary, the ontoformative impact of settler colonialism always circulates back to disability.

Disability thus exhibits its own chronic mobility. It speaks back to settlercolonial biopolitical population management regimes - it does not allow itself to be erased. Disability circulates to reinforce its positionality of power, mobilizing to contest and delegitimize settler-colonial imaginaries of a pure, white, fit, able-bodied and productive national body politic. Across time, through time and in time, disability moves and creates movement, pushing against borders and boundaries, opening up the fringes and edges of settlercolonial anxieties. At times, it is given presence as a means to legitimize the drawing of boundaries around settler-colonial nations; at other times, it is deliberately erased to propel and legitimize the biopolitical violence of settler colonialism on Indigenous bodies. In the end, disability haunts the axis of presence, absence and erasure, despite the settler colonist's violent attempts to keep disability away. Disability's circularity through these settler-colonial regimes always embodies the very vulnerabilities, the breaking down of bodies-and-minds, and the human species' march towards death that the settler-colonial state seeks to erase. Its ever presence distinctly resonates with settler-colonial anxieties of ruin on stolen lands.

\section{Acknowledgements}

I would like to thank Kelly Somers for her editing support, Soma Chatterjee and Tania Das Gupta for their ongoing critical engagement with the paper throughout its development, and the reviewers for their insightful and wellstructured feedback, all of which have been essential to the development of the paper.

\section{References}

Adamson, E., Cortis, N., Brennan, D., \& Charlesworth, S. (2017). Social care and migration policy in Australia: Emerging intersections. Australian Journal of Social Issues, 52(1), 7894.

Amnesty International. (2012). What we found on Nauru. Amnesty International Australia. 


\section{Karen Soldatic}

Amnesty International. (2014). This is still breaking people: update on human rights violations at Australia's asylum seeker processing centre on Manus Island, Papua New Guinea. https://www.amnesty.org/download/Documents/4000/asa120022014en.pdf

Atkinson, J. (1990). Violence in Aboriginal Australia: colonisation and gender. Aboriginal and Islander Health Worker Journal, 14(2), 5-21.

Australian Bureau of Statistics. (2017a). Aboriginal and Torres Strait Islander people with a disability. https://www.abs.gov.au/ausstats/abs@.nsf/mf/4433.0.55.005

Australian Bureau of Statistics. (2017b). 2016 Census. https://www.abs.gov.au/websitedbs/D3310114.nsf/Home/2016\%20QuickStats

Australian Institute of Family Studies. (2016). Child protection and Aboriginal and Torres Strait Islander children, CFCA resource sheet. Australian Government.

Baker, B. (2002). The hunt for disability: the new eugenics and the normalisation of school children. Teachers College Record, 104(4), 663-703.

Barrett, R., \& Barlow, K. (2014, 31 July). Immigration accused of covering up children's mental health issues. ABC News. http://www.abc.net.au/news/2014-07-31/detention-centreinquiry-hears-claims-of-immigration-cover-up/5637654

Bashford, A. (2004). Imperial hygiene: a critical history of colonialism, nationalism and public health. Palgrave Macmillan.

BBC News. (2016, May 21). Syrian refugees in Lebanon face health care crisis - Amnesty. BBC News. http://www.bbc.com/news/world-middle-east-27496889

Bielefeld, S. (2016). Neoliberalism and the return of the guardian state: Micromanaging Indigenous peoples in a new chapter of colonial governance. In W. Sanders (Ed.), Engaging indigenous economy: Debating diverse approaches (pp. 169-181). ANU Press.

Burns, N. (2019). Boundary maintenance: Exploring the intersections of disability and migration. In N. Watson \& S. Vehmas (Eds.), Routledge Handbook of Disability Studies (pp. 331350). Routledge.

Chatterjee, S. (2019). Immigration, anti-racism, and Indigenous self-determination: Towards a comprehensive analysis of the contemporary settler-colonial. Social Identities, 25(5), 664661.

Connell, R. (2011). Southern bodies and disability: Rethinking concepts. Third World Quarterly, $32(8), 1369-1381$.

Cutcher, L., \& Milroy, T. (2010). Mispresenting Indigenous mothers: Maternity allowance and the media. In S. Goodwin \& K. Huppatz (Eds.), The good mother: Contemporary motherhoods in Australia (pp. 153-174). University of Sydney Press.

Day, M. (2019). Disrupting settler nationalism: Gender \& Indigeneity. The Australian Sociological Association Conference Proceedings. Western Sydney University.

Fitts, M., \& Soldatic, K. (2018). Disability income reform and service innovation: Countering racial and regional discrimination. Global Media Journal, 12(1). https://www.hca.westernsydney.edu.au/gmjau/wp-content/uploads/2018/10/GMJAUDisability-Income-Reform-and-Se...ing-Racial-and-Regional-Discrimination.pdf.pdf

Fleay, C. (2015). The limitations of monitoring immigration in Australia. Australian Journal of Human Rights, 21(1), 21-46.

Flynn, M. (2016). From bare life to bureaucratic capitalism: Analyzing the growth of the immigration detention industry as a complex organization. Contemporary Readings in Law and Social Justice, 8(1), 70-79.

Goel, K., \& Penman, J. (2015). Employment experiences of immigrant workers in aged care in regional South Australia. Rural and Remote Health, 15(1), 151-161.

Gorman, R. (2016). Disablement in and for itself: Towards a "global" idea of disability. Somatechnics, 6(1), 249-261.

Hobsbawm, E. (1987). The age of empire. Abacus Books.

Howard-Wagner, D. (2016). Child wellbeing and protection as a regulatory system in the neoliberal age: Forms of Aboriginal agency and resistance engaged to confront the challenges for Aboriginal people and community-based Aboriginal organisations. Australian Indigenous Law Review, 19(1), 88-102. 
Human Rights and Equal Opportunity Commission. (1997). Bringing them home: Report of the national inquiry into the separation of Aboriginal and Torres Strait Islander children from their families. https://humanrights.gov.au/our-work/bringing-them-home-report-1997

Jakubowicz, A., \& Meekosha, H. (2003). Can multiculturalism encompass disability? In S. Riddell \& N. Watson (Eds.), Disability, culture and identity (pp. 180-199). Pearson Education.

Jarman, M., Lamp, S., Mitchell, D., Nepveux, D., Nowell, N., \& Snyder, S. (2002). Theorising disability as political subjectivity: Work by the UIC Disability Collective on political subjectivities. Disability \& Society, 17(5), 555-569.

Levy, D., \& Peart, S. (2004). Statistical prejudice: From eugenics to immigrants. European Journal of Political Economy, 20(1), 5-22.

Marchetti, E. (2006). The deep colonizing practices of the Australian Royal Commission into Aboriginal deaths in custody. Journal of Law and Society, 33(3), 451-474.

Malone, A. (2014). Ideal motherhood and surveillance: Young mothers with disabilities and their share of stories. In G. Filax \& D. Taylor (Eds.), Disabled mothers: Stories and scholarship by and about mothers with disabilities (pp. 195-241). Demeter Press.

Miller, M., Hager, T., \& Bromwich, R. (2017). Bad mothers: Regulations, representations and resistance. Demeter Press.

Mitchell, D., \& Snyder, S. (2015). The biopolitics of disability: Neoliberalism, ablenationalism, and peripheral embodiments. University of Michigan Press.

Morgensen, P. (2011). The biopolitics of settler colonialism: Right here, right now. Settler Colonial Studies, 1(1), 52-76.

Morrison-Dayan, R. (2019). A viable care migration programme for Australia's ageing population: Recruiting migrant personal care workers for Australian aged care. Australian Journal of Social Issues, 54(4), 371-385.

National Ethnic Disability Alliance. (2015). The plight of people living with disabilities within Australian immigration detention: Demonized, detained and disowned. http://www.neda.org.au/index.php/publications/plight-people-living-disabilities-withinaustralian-immigration-detention-demonised

Peisker, V., \& Tilbury, F. (2006). Employment niches for recent refugees: Segmented labour markets in twenty-first century Australia. Journal of Refugee Studies, 19(2), 203-229.

Povinelli, E. (2011). The governance of the prior. Interventions: International Journal of Postcolonial studies, 13(1), 13-30.

Poynting, S., \& Briskman, L. (2018). Islamophobia in Australia: From far-right deplorables to respectable liberals. Social Sciences, 7(11), 213-229.

Ravenscroft, A. (2012). The postcolonial eye: White Australian desire and the visual field of race. Ashgate.

Reid, A., Peters, S., Felipe, N., Lengeurrand, E., \& Harding, S. (2016). The impact of migration on deaths and work-related injuries in Australia. Australian and New Zealand Journal of Public Health, 40(1), 49-54.

Rice, S., Day, A., \& Briskman, L. (2018). Social work in the shadow of the law. Federation Press.

Rose, D. (1999). Indigenous ecologies and an ethic of connection. In N. Low (Ed.), Global Ethics and Environment (pp. 176-199). Routledge.

Rose, D. (2004). Reports from a wild country: Ethics for decolonisation. UNSW Press.

Soldatic, K. (2015). Postcolonial reproductions: Disability, indigeneity and the formation of the white masculine settler state of Australia. Social Identities: Journal for the Study of Race, Nation and Culture, 21(1), 53-68.

Soldatic, K. (2018). Policy mobilities of exclusion: Implications of Australian disability pension retraction for Indigenous Australians. Social Policy and Society, 17(1), 151-167.

Soldatic, K. (2019). Disability and neoliberal state formations. Routledge.

Soldatic, K. (2020). Disability-Indigeneity gendered relations in settler-colonial Australia: Continuities, trajectories and enmeshments. In C. Spivakovsky, L. Steele, \& P. Weller (Eds.), The legacies of institutionalisation: Disability, law and policy in the 'deinstitutionalised' community (pp. 171-189). Hart Publishing. 


\section{Karen Soldatic}

Soldatic, K., \& Fiske, L. (2009). Bodies locked up: Intersections of disability and race in Australian immigration. Disability \& Society, 24(3), 289-301.

Soldatic, K. \& Fitts, M. (2020). Who's caring for whom? Disabled Indigenous carers experiences of Australia's infrastructures of social protection. Journal of Family Studies. https://doi.org/10.1080/13229400.2020.1734478

St Guillaume, L., \& Finlay, E. (2018). Disabled mobility and the production of impairment: the case of Australia's migration policy framework. Asia Pacific Review, 59(1), 119-131.

Strakosch, E. (2016). Neoliberal Indigenous policy: settler colonialism and the 'post-welfare' state. Palgrave Macmillan.

United Nations Human Rights Commission. (2019). Global trends: forced displacement in 2018. https://www.unhcr.org/5d08d7ee7.pdf

Veracini, L. (2014). Understanding colonialism and setter colonialism as distinct formations. Interventions, 16(5), 615-633.

Wahlquist, C. (2017, October 26). Indigenous voice proposal 'not desirable', says Turnbull. The Guardian. https://www.theguardian.com/australia-news/2017/oct/26/indigenous-voiceproposal-not-desirable-says-turnbull

Walter, M. (2016). Social exclusion/inclusion for urban Aboriginal and Torres Strait Islander people. Social Inclusion, 4(1), 68-76.

Watkins, J. (2017). Australia's irregular migration information campaigns: Border externalization, spatial imaginaries and extraterritorial subjugation. Territory, Politics, Governance, 5(3), 282-303.

Wolfe, P. (2006). Settler-colonialism and the elimination of the native. Journal of Genocide Research, 8(4), 387-409. 